\title{
A Profile of Glucose-6-Phosphate Dehydrogenase Variants and Deficiency of Multicultural Families in Korea
}

\author{
Young Yil Bahk ${ }^{1}$, Seong Kyu Ahn², Jinyoung Lee ${ }^{3}$, Jae Hyoung $\mathrm{Im}^{4}$, Joon-Sup Yeom5, Sookkyung Park', \\ Jeongran Kwon ${ }^{6}$, Hyesu Kan ${ }^{6}$, Miyoung Kim ${ }^{6}$, Woori Jang ${ }^{7, *}$, Tong-Soo Kim ${ }^{3,8, *}$ (i) \\ ${ }^{1}$ Department of Biotechnology, College of Biomedical and Health Science, Konkuk University, Chungju 27478, Korea; ${ }^{2}$ Infectious Diseases \\ Investigation Division, Jeonnam Institute of Public Health and Environment, Muan 58568, Korea; ' ${ }^{2}$ Department of Parasitology and Tropical Medicine \\ \& Global Resource Bank of Parasitic Protozoa Pathogens, Inha University School of Medicine, Incheon 22212, Korea; ${ }^{4}$ Division of Infection Diseases, \\ Department of Internal Medicine, Inha University School of Medicine, Incheon 22212, Korea; ${ }^{5}$ Department of Internal Medicine, Yonsei University \\ College of Medicine, Seoul 03722, Korea; ${ }^{6}$ Bureau of Infectious Disease Policy, Korea Disease Control and Prevention Agency, Osong 28159, \\ Korea; ${ }^{7}$ Department of Laboratory Medicine, Inha University School of Medicine, Incheon 22212, Korea; ${ }^{8}$ Convergence Research Center for Insect \\ Vectors, Incheon National University, Incheon 22012, Korea
}

\begin{abstract}
Vivax malaria incidence in Korea is now decreased and showing a low plateau. Nowadays, vivax malaria in Korea is expected to be successfully eliminated with anti-malaria chemotherapy, primaquine, and vector control. The glucose-6-phosphate dehydrogenase (G6PD) deficiency is associated with potential hemolytic anemia after primaquine administration. This inborn disorder has a pivotal polymorphism with genetic variants and is the most prevalent $\mathrm{X}$-chromosome-linked disorder. The prevalence of G6PD deficiency was previously reported negligible in Korea. As the population of multicultural families pertaining marriage immigrants and their adolescents increases, it is necessary to check G6PD deficiency for them prior to primaquine treatment for vivax malaria. The prevalence of G6PD variants and G6PD deficiency in multicultural families was performed in 7 counties and 2 cities of Jeollanam-do (Province), Gyeonggi-do, and Gangwon-do. A total of 733 blood samples of multicultural family participants were subjected to test the phenotypic and genetic G6PD deficiency status using G6PD enzyme activity quantitation kit and PCR-based G6PD genotyping kit. The G6PD phenotypic deficiency was observed in 7.8\% of male adolescent participants and $3.2 \%$ of materfamilias population. Based on the PCR-based genotyping, we observed total 35 participants carrying the mutated alleles. It is proposed that primaquine prescription should seriously be considered prior to malaria treatment.
\end{abstract}

Key words: G6PD deficiency, multicultural family, primaquine, Korea

\section{INTRODUCTION}

Glucose-6-phosphate dehydrogenase (G6PD) is an X-chromosome (Xq28)-linked housekeeping cytoplasmic enzyme. It has a redox function as the first enzyme of the pentose-phosphate pathway involving in the generation of NADPH, an electron donor required for many biosynthetic processes or to counter the damaging effects of oxygen radicals [1,2]. It is one of the most polymorphic proteins, in which at least 140 mutations have been identified [3,4]. G6PD deficiency produces various clinical presentations. It is the most common enzy-

\footnotetext{
- Received 20 July 2021, revised 11 August 2021, accepted 11 August 2021.

*Corresponding authors (jangwr@inha.ac.kr; tongsookim@inha.ac.kr)

(c) 2021, Korean Society for Parasitology and Tropical Medicine

This is an Open Access article distributed under the terms of the Creative Commons Attribution Non-Commercial License (https://creativecommons.org/licenses/by-nc/4.0) which permits unrestricted non-commercial use, distribution, and reproduction in any medium, provided the original work is properly cited.
}

mopathy of humans over 400 million individuals throughout the world, showing as high frequency as $30 \%$ in tropical Africa, parts of the Middle East, and Southeast Asia. The G6PD deficient individuals are usually asymptomatic but acute hemolysis may occur with oxidative stress induced by ingestion of drugs, certain type of food, exposing to certain chemical substances or when there is accompanying infection or hypoxia [5]. Numerous lines of evidence indicate that the geographic correlation of its distribution with the historical endemicity of malaria and suggest that the defect has risen in frequency through natural selection by malaria [6-8]. Recently, it was known that studies carried on the Korean population showed no cases representing above severe G6PD deficiency [9-11]. The higher frequencies of the defect were reported from Africa, Asia, the Mediterranean region, and the Middle East, owing to recent migrations and perpetual communications. The disorder was also reported from North and South America and 
even from the European countries [12].

Although there has been a mixed pattern of repeated increases and decreases, the vivax malaria incidence in Korea has generally shown a plateau (around 1 incidence rate per 100,000) since its re-emerging in 1993 and the highest patient outbreak in $2000(4,142$ confirmed and indigenous cases, 8.98 incidence rate per 100,000) [13]. Despite such a declined and steady state, there remain tasks to be achieved for vivax malaria elimination from Korea.

In general, it is well established that the spatial extent of vivax malaria overlaps widely with that of G6PD deficiency. The antimalarial licensed for the radical cure and relapse prevention for vivax malaria, is only primaquine. It, unfortunately, can trigger severe hemolytic anemia, particularly in G6PD deficient individuals [14]. The World Health Organization (WHO) recommends primaquine at a dose of $0.25-0.5 \mathrm{mg} / \mathrm{kg}$ of body weight for 14 days in all vivax malaria patients with normal G6PD activity [15]. G6PD testing is not generally accessible in most malaria-endemic regions. It is, therefore, lower dosages of primaquine are recommended to reduce the risk for the suspected G6PD deficient patients [16].

As previously documented, due to the low prevalence in Korea, G6PD deficiency testing has not been executed. However, G6PD deficient patients have been continually reported since 1984. G6PD deficiency-related hemolytic anemia patients in Korea Army were confirmed after primaquine administration without G6PD deficiency testing [11,17]. In addition, recently, multicultural families have been on the rise due to the increase in immigrants from Southeast Asian countries, where frequency of G6PD deficiency is as high as 30\%. In Korea, proportion of the multicultural families is $4.3 \%$, similar to $5 \%$ in the countries of the Organization for Economic Cooperation and Development [18]. Moreover, the multicultural families in Korea mostly composed of maternal immigrants. It is expected that the G6PD deficiency rate of children of these families increase.

This study was aimed to figure out the G6PD deficiency profile of the adolescents in multicultural families and to establish a basis for the G6PD screening test before primaquine administration, and to survey on recognition of the multicultural family center for the G6PD deficients.

\section{MATERIALS AND METHODS}

\section{Ethics statement, collection sites and sample collection}

This study was reviewed and approved by the Institutional
Review Board of the Inha University Hospital (Approval No. 2020-04-004) and conducted according to the principles expressed in the 1964 Helsinki Declaration. This study was conducted with extensive cooperation from the local multicultural family centers and the local public health authorities. In conjunction with the multicultural centers in each province involved in this study, genotype analysis of G6PD, enzyme activity measurement and blood test were performed to investigate G6PD deficiency among the adolescents in multicultural families and the maternal multicultural members from 10 countries. Written informed consents were obtained from participants themselves and their parents or student's guardians to collect a blood sample prior to personal information talking obtained through interviews and questionnaires. The questionnaire was focused on demographic characteristics analysis and on previous medical history or the composition of the entire family. A total 733 blood samples were collected from the study population: 417 from the adolescents in multicultural families (219 females and 198 males) and 316 from the maternal multicultural members. The blood samples were collected from venous puncture ( $3 \mathrm{ml}$ in $\mathrm{K}_{2}$ EDTA vacutainer tubes), and analyzed using standard quantitative G6PD enzymatic assay.

\section{Determination of G6PD deficiency}

G6PD and hemoglobin $(\mathrm{Hb})$ testing by venipuncture was carried out with G6PD quantitative kinetic UV assay using whole blood kit (Cat. No. G6P8905; BEN-Biochemical Enterprise S.r.l., Milano, Italy) according to the manufacturer's instructions. The blood samples were transferred to the Seoul Clinical Laboratories (Yongin, Korea) within $24 \mathrm{hr}$ after collected under appropriate storage conditions to quantitate enzyme activity of G6PD [19].

\section{DNA extraction and analysis on G6PD variants}

Genomic DNA was extracted from $200 \mu \mathrm{l}$ of whole blood using QIAamp DNA Blood Mini Kit (Qiagen GmbH, Hilden, Germany) according to the manufacturer's instruction. Extracted DNA samples were diagnosed using DiaPlexC ${ }^{\mathrm{TM}}$ G6PD Genotyping Kit (Asian type, SolGent Co., Ltd., Daejeon, Korea) based on the multiplex allele-specific PCR based assay system for screening G6PD deficiency according to the manufacturer's instruction. It detects specifically the 7 Asian variants of the G6PD gene via one-step PCR. The variant each produce PCR products of different sizes: Vanua Lava $(383 \mathrm{~T} \rightarrow \mathrm{C}$, prod- 
uct size: $154 \mathrm{bp}$ ), Mahidol (487 G $\rightarrow \mathrm{A}, 337 \mathrm{bp}$ ), Mediterranean (563 C $\rightarrow$ T, 262 bp), Coimbra (592 C $\rightarrow T, 243$ bp), Viangchan $(871 \mathrm{G} \rightarrow \mathrm{A}, 501 \mathrm{bp})$, Union $(1,360 \mathrm{C} \rightarrow \mathrm{T}, 803 \mathrm{bp})$, Canton $(1,376 \mathrm{G} \rightarrow \mathrm{T}, 681 \mathrm{bp})$, and Kaiping $(1,388 \mathrm{G} \rightarrow \mathrm{A}, 557$ bp). The PCR round was performed under the following conditions: $95^{\circ} \mathrm{C}$ for $1 \mathrm{~min}$, followed by 35 cycles at $95^{\circ} \mathrm{C}$ for 30 $\mathrm{sec}, 60^{\circ} \mathrm{C}$ for $30 \mathrm{sec}$, and 72 for $40 \mathrm{sec}$, and a final extension at $72^{\circ} \mathrm{C}$ for $5 \mathrm{~min}$. The amplification reaction was carried out in $20 \mu \mathrm{l}$ volume reactions, including primer volumes $(2 \mu \mathrm{l}$ each of forward and reverse primers, 10 pmole $/ \mathrm{ml}), 12.5 \mu \mathrm{l}$ of PCR Smart mix, and $3 \mu \mathrm{l}$ of DNA template. PCR products were resolved by agarose electrophoresis on 1\% agarose gel and stained with SYBR Safe DNA GelStain ${ }^{\mathrm{TM}}$ (Thermo Fisher Scientific, Waltham, Massachusetts, USA).

\section{RESULTS}

\section{Demographic characteristics of study population}

A total of 733 multicultural family members (316 foreign immigrant women and their 417 adolescents in multicultural families) were included in the analysis (Table 1). Of the adolescents, $53 \%$ were male and $8.8 \pm 4.1$ years $(9.0 \pm 4.1$ years for female). The materfamilias (foreign immigrant women) were $34.9 \pm 8.0$ years (Table 2). The major country of origin of the adolescent's mothers (materfamilias population) in our study population were of Vietnam (252 individuals, 60.4\% [252/ 417]), followed by Philippines (77, 18.5\%), Cambodia (58, 13.9\%), and Thailand (13, 3.1\%) (Table 3). For foreign immigrant women (materfamilias population), 58.9\% (186/316) were from Vietnam, followed by Philippines (20.9\%, 66/316),

Table 1. Participants in this study including materfamilias (marriage immigrant women) population and adolescent population

\begin{tabular}{|c|c|c|c|c|c|c|c|c|c|c|c|c|c|}
\hline \multirow{2}{*}{ Province } & \multirow{2}{*}{ County } & \multirow{2}{*}{ Adolescents } & \multicolumn{10}{|c|}{ Materfamilias } & \multirow{2}{*}{ Tota } \\
\hline & & & Viet. & Phil. & Camb. & Thai. & Laos & Kazakh. & Uzbek. & Indon. & Russia & China & \\
\hline \multirow[t]{5}{*}{ Gangwon } & Goseong & 42 & 15 & 12 & 0 & 1 & 0 & 0 & 0 & 0 & 0 & 0 & 28 \\
\hline & Yangyang & 40 & 18 & 9 & 1 & 0 & 0 & 0 & 0 & 0 & 0 & 0 & 28 \\
\hline & Donghae & 28 & 23 & 6 & 2 & 2 & 2 & 0 & 0 & 0 & 0 & 0 & 35 \\
\hline & Taebaek & 21 & 8 & 0 & 2 & 0 & 1 & 1 & 1 & 0 & 0 & 0 & 13 \\
\hline & Subtotal & 131 & 64 & 27 & 5 & 3 & 3 & 1 & 1 & 0 & 0 & 0 & 104 \\
\hline \multirow[t]{5}{*}{ Jeonnam } & Hwasun & 68 & 26 & 5 & 19 & 0 & 0 & 0 & 0 & 0 & 0 & 0 & 50 \\
\hline & Haenam & 16 & 22 & 4 & 6 & 0 & 0 & 0 & 2 & 0 & 1 & 1 & 36 \\
\hline & Boseong & 93 & 31 & 12 & 0 & 3 & 0 & 0 & 0 & 1 & 0 & 0 & 47 \\
\hline & Hampyeong & 69 & 15 & 15 & 13 & 0 & 0 & 0 & 0 & 2 & 0 & 0 & 45 \\
\hline & Subtotal & 246 & 94 & 36 & 38 & 3 & 0 & 0 & 2 & 3 & 1 & 1 & 178 \\
\hline \multirow[t]{2}{*}{ Gyeonggi } & Yeoncheon & 40 & 28 & 3 & 0 & 0 & 0 & 0 & 0 & 0 & 0 & 3 & 34 \\
\hline & Subtotal & 40 & 28 & 3 & 0 & 0 & 0 & 0 & 0 & 0 & 0 & 3 & 34 \\
\hline Total & & 417 & 186 & 66 & 43 & 6 & 3 & 1 & 3 & 3 & 1 & 4 & 316 \\
\hline
\end{tabular}

Viet.: Vietnam, Phil.: Philippines, Camb.: Cambodia, Thai.: Thailand, Kazakh.: Kazakhstan, Uzbek.: Uzbekistan, Indon.: Indonesia.

Table 2. Demographic characteristics of participants surveyed

\begin{tabular}{|c|c|c|c|c|}
\hline Characteristics & $\begin{array}{c}\text { Materfamilias } \\
\quad(n=316)\end{array}$ & $\begin{array}{l}\text { Adolescents (Male) } \\
\qquad(n=219)\end{array}$ & $\begin{array}{c}\text { Adolescents } \\
\text { (Female) }(n=198)\end{array}$ & $\begin{array}{l}\text { Adolescents (Total) } \\
\quad(n=417)\end{array}$ \\
\hline Age $(y r)$, mean $\pm S D$ & $34.9 \pm 8.0$ & $8.7 \pm 4.1$ & $9.0 \pm 4.1$ & $8.8 \pm 4.1$ \\
\hline $\mathrm{Hb}$ count (g/dL), mean $\pm \mathrm{SD}$ & $13.2 \pm 1.2$ & $13.5 \pm 1.1$ & $13.0 \pm 1.1$ & $13.2 \pm 1.1$ \\
\hline Mean G6PD activity (U/g Hb), mean \pm SD & $11.5 \pm 2.7$ & $11.6 \pm 2.8$ & $12.3 \pm 2.0$ & $11.9 \pm 2.4$ \\
\hline G6PD deficient [n (\%)] & $10(3.2 \%)$ & $17(7.8 \%)$ & $4(2.0 \%)$ & $21(5.0 \%)$ \\
\hline Extreme G6PD activity, mean \pm SD & $20.2 \pm 3.7$ & $21.6 \pm 0.5$ & $19.0 \pm 2.4$ & $19.9 \pm 2.3$ \\
\hline \multicolumn{5}{|l|}{ WHO classification of deficiency } \\
\hline Severe $(<10 \%)$ & $1(0.3 \%)$ & $11(5.0 \%)$ & & $11(2.6 \%)$ \\
\hline Moderate (10\% to <30\%) & $4(1.3 \%)$ & $4(1.8 \%)$ & $1(0.5 \%)$ & $5(1.2 \%)$ \\
\hline Mild (30\% to <60\%) & $5(1.6 \%)$ & $2(0.9 \%)$ & $3(1.5 \%)$ & $5(1.2 \%)$ \\
\hline Normal ( $\geq 60 \%$ to <150\%) & $295(93.4 \%)$ & $200(91.3 \%)$ & $190(96.0 \%)$ & $390(93.5 \%)$ \\
\hline Extreme $(\geq 150 \%$ or $>16.3 \mathrm{U} / \mathrm{g} \mathrm{Hb})$ & $11(3.5 \%)$ & $2(0.9 \%)$ & $4(2.0 \%)$ & $6(1.4 \%)$ \\
\hline
\end{tabular}


Table 3. Distribution of the adolescent population in the multicultural families in this study

\begin{tabular}{|c|c|c|c|c|c|c|c|c|c|c|c|c|c|c|}
\hline \multirow{3}{*}{ Counties } & \multicolumn{12}{|c|}{ Countries of Materfamilias } & \multirow{2}{*}{\multicolumn{2}{|c|}{ Sub-total }} \\
\hline & \multicolumn{2}{|c|}{ Vietnam } & \multicolumn{2}{|c|}{ Philippines } & \multicolumn{2}{|c|}{ Cambodia } & \multicolumn{2}{|c|}{ Thailand } & \multicolumn{2}{|c|}{ Laos } & \multicolumn{2}{|c|}{$\begin{array}{c}\text { Other } \\
\text { Countriesa }\end{array}$} & & \\
\hline & Male & Female & Male & Female & Male & Female & Male & Female & Male & Female & Male & Female & Male & Female \\
\hline \multirow[t]{2}{*}{ Goseong } & 8 & 15 & 6 & 10 & 0 & 0 & 1 & 2 & 0 & 0 & 0 & 0 & 15 & 27 \\
\hline & $1^{b}$ & 1 & & 1 & & & & & & & & & 1 & 2 \\
\hline Yangyang & $\begin{array}{l}18 \\
12^{c}\end{array}$ & 9 & $1^{6}$ & 4 & 1 & 2 & 0 & 0 & 0 & 0 & 0 & 0 & \multicolumn{2}{|l|}{$2^{25} 2$} \\
\hline Donghae & $1^{8}$ & 13 & $1^{3}$ & 0 & 1 & 0 & 2 & 0 & $1^{1}$ & 0 & 0 & 0 & $3^{15}$ & 13 \\
\hline Taebaek & 7 & 6 & 0 & 0 & 3 & 1 & 0 & 0 & 1 & 0 & 2 & 1 & $\begin{array}{l}13 \\
2\end{array}$ & 8 \\
\hline Hwasun & $\begin{array}{l}27 \\
1\end{array}$ & 11 & 1 & 3 & 9 & $2^{17}$ & 0 & 0 & 0 & 0 & 0 & 0 & $\begin{array}{l}37 \\
1\end{array}$ & $2^{31}$ \\
\hline Haenam & 6 & 2 & 0 & 1 & $1^{3}$ & 4 & 0 & 0 & 0 & 0 & 0 & 0 & $1^{9}$ & 7 \\
\hline Boseong & 32 & 31 & 9 & 11 & 0 & 0 & 3 & $5_{1}$ & 0 & 0 & 2 & 0 & 46 & $\begin{array}{l}47 \\
1\end{array}$ \\
\hline Hampyeong & 15 & 12 & 12 & 9 & $4^{8}$ & $9_{1}$ & 0 & 0 & 0 & 0 & 4 & 0 & $4^{39}$ & 30 \\
\hline Yeoncheon & $1^{17}$ & ${ }_{1}^{15}$ & 1 & 1 & 0 & 0 & 0 & 0 & 0 & 0 & 2 & 4 & $1^{20}$ & ${ }^{20}$ \\
\hline Total & 138 & 114 & 38 & 39 & 25 & 33 & 6 & 7 & 2 & 0 & 10 & 5 & 219 & 198 \\
\hline & 43 & 11 & 2 & 1 & 5 & 21 & & 1 & 1 & & 2 & & 125 & 43 \\
\hline
\end{tabular}

aOther countries contain Kazakhstan, Uzbekistan, Indonesia, Russia, and China.

bItalic and red-colored numbers mean the numbers of deficient individuals in both enzyme-activity and genotype.

'Green-colored numbers mean the numbers of deficient individuals in enzyme activity, but not in genotype.

${ }^{\mathrm{d} B l u e-c o l o r e d ~ n u m b e r s ~ m e a n ~ t h e ~ n u m b e r s ~ o f ~ d e f i c i e n t ~ i n d i v i d u a l s ~ i n ~ g e n o t y p e, ~ b u t ~ n o t ~ i n ~ e n z y m e-a c t i v i t y . ~}$

Table 4. Distribution of the foreign immigrant woman population in the multicultural families in this study

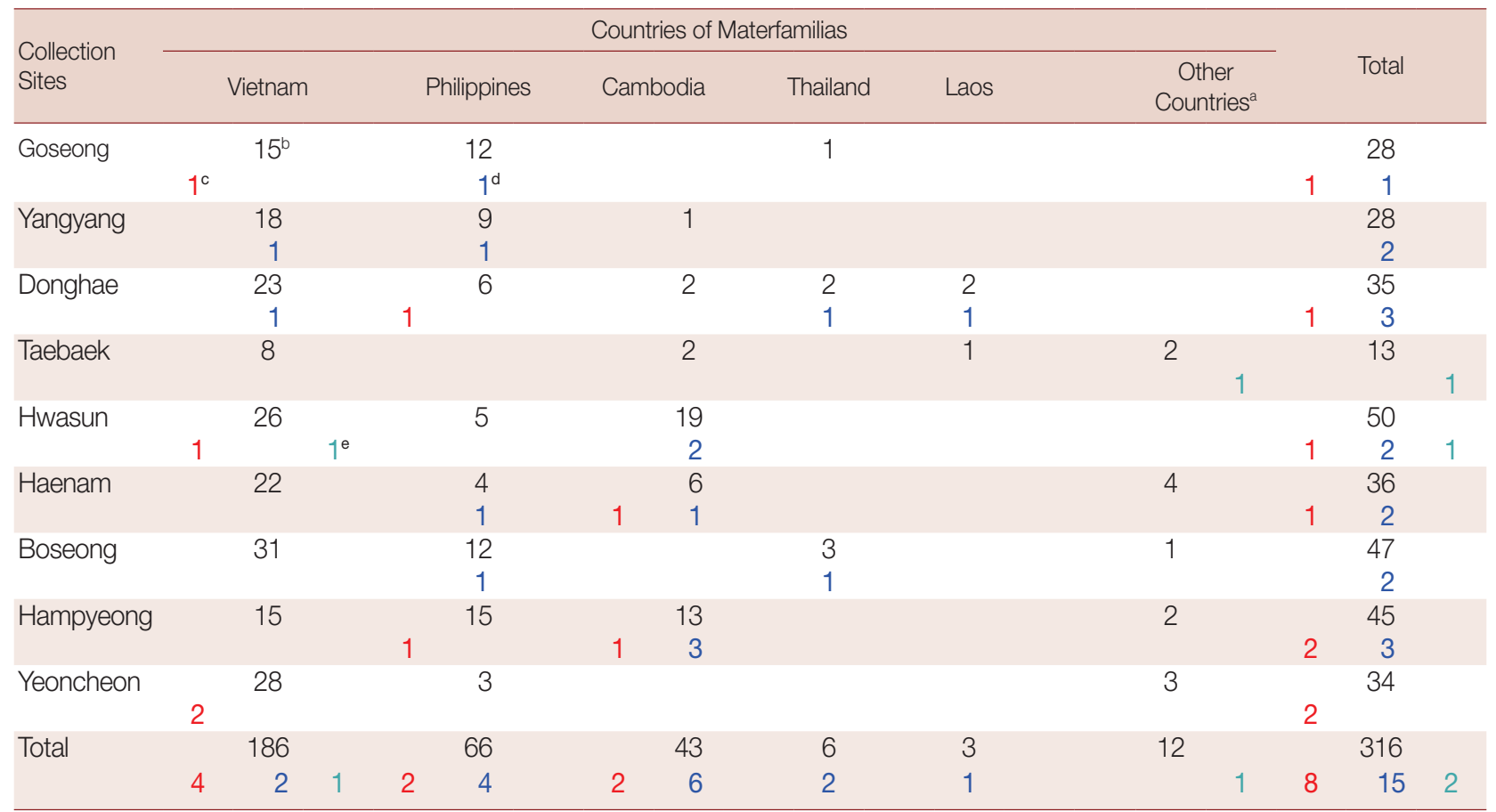

aOther countries contain Kazakhstan, Uzbekistan, Indonesia, Russia, and China.

${ }^{\mathrm{b}}$ Total number of the foreign immigrant women which were tested for the G6PD activity.

${ }^{\mathrm{C}}$ Red-colored numbers mean the numbers of deficient individuals in both enzyme-activity and genotype.

${ }^{\mathrm{B}}$ Blue-colored numbers mean the numbers of deficient individuals in genotype, but not enzyme-activity (Normal range).

${ }^{e}$ Green-colored numbers mean the numbers of deficient individuals in enzyme activity, but not genotype. 
Cambodia (13.6\%, 43/316), and Thailand (1.9\%, 6/316) (Table 4). The other countries were Laos (3), Kazakhstan (1), Uzbekistan (3), Indonesia (3), Russia (1), and China (4).

For the blood samples, hemoglobin ( $\mathrm{Hb})$ level was measured whether the donors were anemic or not. Hb level of the adolescents was $13.2 \pm 1.1 \mathrm{~g} / \mathrm{dl}$ and the materfamilias $13.2 \pm$ $1.2 \mathrm{~g} / \mathrm{dl}$. Any child in our study did not experience severe anemia at our interview (Table 2).

\section{Prevalence of G6PD phenotypic deficiency}

The G6PD activity distribution of all 733 samples are shown in Fig. 1. According to the WHO's G6PD testing guidelines, value less than $10 \%, 10$ to $<30 \%, 30$ to $>60 \%$ of the median are defined as severe, moderate, and mild deficient (normal range: 7.9-16.3 U/g Hb). Prevalence of G6PD deficiency is presented in Table 2. There were 17 participants showing extreme G6PD activity (>16.3 U/g Hb) having 19.6 $\pm 4.5 \mathrm{U} / \mathrm{g} \mathrm{Hb}$ (20.2 $\pm 3.7 \mathrm{U} / \mathrm{g} \mathrm{Hb}$ in 11 materfamilias, $19.9 \pm 2.3 \mathrm{U} / \mathrm{g} \mathrm{Hb}$ in 6 adolescents. $21.6 \pm 0.5 \mathrm{U} / \mathrm{g} \mathrm{Hb}$ in 2 male adolescents, and $19.0 \pm 2.4 \mathrm{U} / \mathrm{g} \mathrm{Hb}$ in 4 female adolescents). The 21 (5.0\% of 417) adolescents exhibited G6PD enzyme activity deficiency: 11 severe deficients, 5 moderate, and 5 mild ones. The enzyme activity in the deficient adolescents were $0.5-22.5 \mathrm{U} / \mathrm{g} \mathrm{Hb}$. Seventeen male adolescents (7.8\%) showed deficient phenotype and 4 females (2.0\%) exhibited mild G6PD deficiency. In the materfamilias population, the enzyme activity was $11.5 \pm 2.7$ $\mathrm{U} / \mathrm{g} \mathrm{Hb}$ (Table 2). Ten participants of materfamilias population exhibited G6PD deficiency phenotype (3.2\%); 1 severe $(0.3 \%), 4$ moderate $(1.3 \%)$, and 5 mild $(1.6 \%)$. Their mean value was $4.3 \pm 1.8 \mathrm{U} / \mathrm{g} \mathrm{Hb}$ (ranged from $<0.5$ to 6.2 ).

\section{G6PD genetic variant}

Of the 733 blood samples, 8 genetic variants in G6PD gene were detected: Vanua Lava $(383 \mathrm{~T} \rightarrow \mathrm{C})$, Mahidol $(487 \mathrm{G} \rightarrow \mathrm{A})$, Mediterranean (563 $\mathrm{C} \rightarrow \mathrm{T}$ ), Coimbra (592 $\mathrm{C} \rightarrow \mathrm{T}$ ), Viangchan $(871 \mathrm{G} \rightarrow \mathrm{A})$, Union $(1,360 \mathrm{C} \rightarrow \mathrm{T})$, Canton $(1,376 \mathrm{G} \rightarrow \mathrm{T})$, and Kaiping $(1,388 \mathrm{G} \rightarrow \mathrm{A})$. Upon genotyping of the male adolescents, we observed 17 hemizygous mutant individuals (7.8\%) including 5 unknown mutation cases, which were not shown mutant genotype by PCR test with Asian type kit, but were with G6PD deficiency (Table 5). The most common polymorphism in the adolescents was Viangchan variant (47.1\%), followed by other mutated allele variant(s) (29.4\%), Canton (11.8\%), Vanua Lava (5.9\%) and Kaiping variant (5.9\%) (Fig. 1B). The previously unknown mutated allele variants were with measured G6PD deficiency, which were ranged from 3.2 to $6.4 \mathrm{U} / \mathrm{g} \mathrm{Hb}$ (mean \pm SD: $4.2 \pm 1.2 \mathrm{U} / \mathrm{g} \mathrm{Hb}$ ), whereas G6PD enzyme activities of hemizygous males were ranged from $<0.5$ to $1.7 \mathrm{U} / \mathrm{g} \mathrm{Hb}$ (mean \pm SD: $0.6 \pm 0.4 \mathrm{U} / \mathrm{g} \mathrm{Hb}$ ). Upon genotyping the female adolescents, 7 females found carrying the G6PD variants. The polymorphisms were Viangchan (57.1\%) and Kaiping variants (42.9\%). Of the 7 participants carrying the mutated allele, 3 female participants showed the enzyme activity in normal range (10.5-11.7 U/g Hb), but their genetic tests determined them to be deficient (Table 5). The materfamilias group were determined to $4.7 \%$ heterozygous females without G6PD deficiency, 2.2\% single mutant females, $0.3 \%$ compound heterozygous mutant females, and $0.6 \%$ other unknown mutated allele (s) (Table 5). In the heterozygous mutants, the most common polymorphism was Viangchan variant (52\%), followed by Kaiping (16\%), Union (12\%), Vanua Lava (8\%) and Canton variants (8\%) (Fig. 1D). Based on the PCR genotyping, there was no homozygous mutant in immigrant women participant. One participant of this population carried double variants of Viangchan and Canton (the enzyme activity: $<0.5 \mathrm{U} / \mathrm{g} \mathrm{Hb}$ ) showing the compound heterozygosity. Of the 25 foreign immigrant women (the materfamilias population) having G6PD polymorphism, 15 participants were not G6PD deficiency, which ranged 8-12.1 U/g Hb $(9.7 \pm 1.1 \mathrm{U} / \mathrm{g}$ $\mathrm{Hb}$ ). However, mean G6PD enzyme activity among heterozygous individuals without G6PD deficiency was approximately $15.7 \%$ and $17.8 \%$ lower than total mean value and mean value of normal individuals, respectively $(9.7 \pm 1.1 \mathrm{U} / \mathrm{g}$ Hb vs. $11.5 \pm 2.7 \mathrm{U} / \mathrm{g}$ Hb vs. $11.8 \pm 2.5 \mathrm{U} / \mathrm{g} \mathrm{Hb}$ ) (Tables 2,5 ). Heterozygous females were predicted to have $2.1 \mathrm{U} / \mathrm{g}$ Hb lower mean G6PD activity than their wild-type counterparts. The distribution of G6PD genotypes in this population was not associated with their ethnicity. That is, the genotype by country was not significant.

\section{DISCUSSION}

Vivax malaria is still an important public health problem in Korea, particularly near the DMZ in the northern part of Gyeonggi-do, including Gimpo and Paju, and Gangwon-do [13]. In fact, vivax malaria elimination in Korea is generally expected to be successful. However, there are a number of points for consideration against malaria elimination. In this globalized era, international intercourses are frequent due to mutual exchanges and travel between many countries. Further- 
A

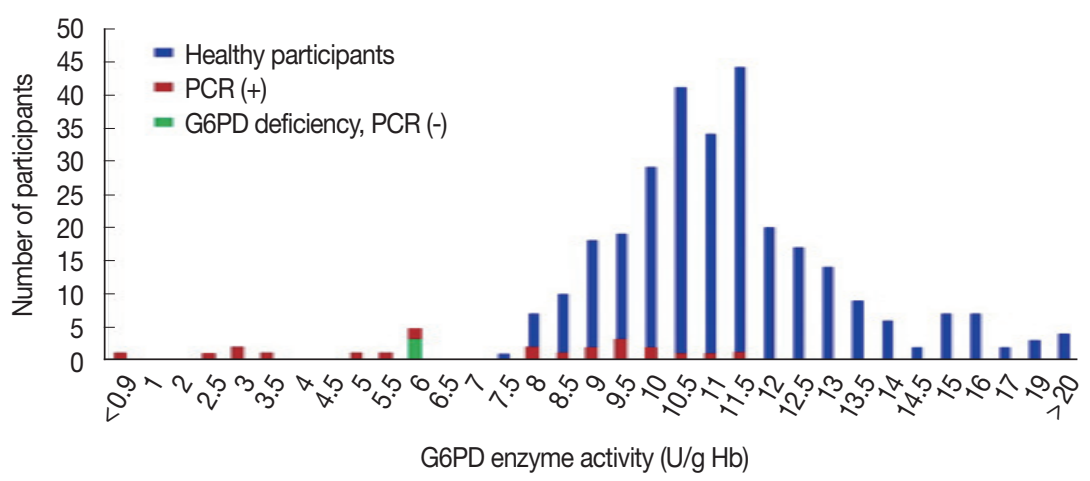

B

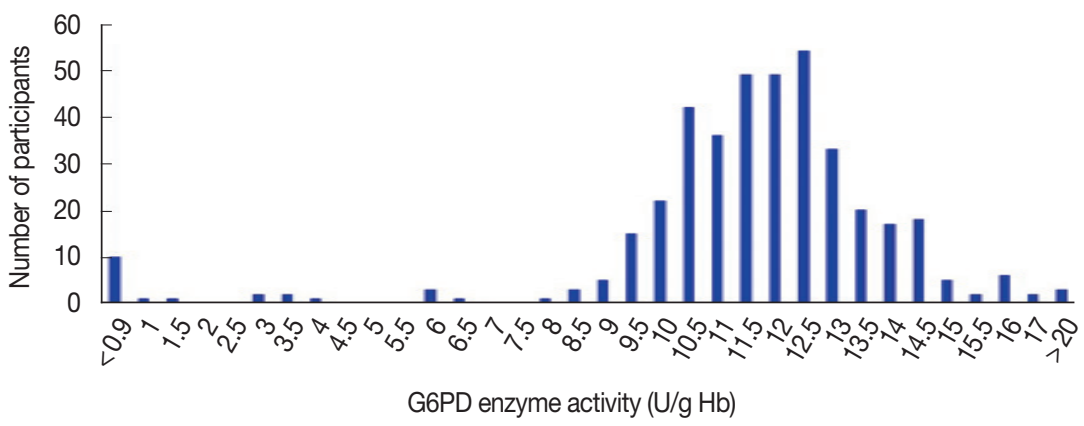

C

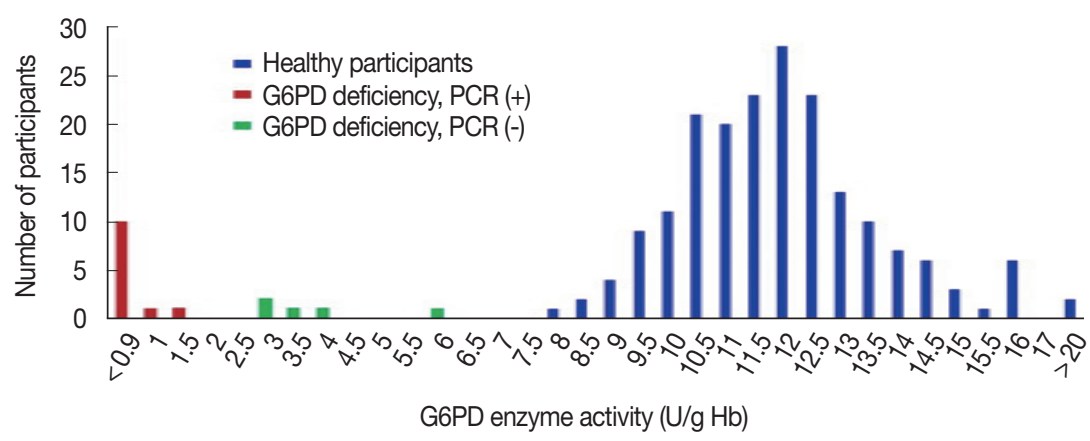

D

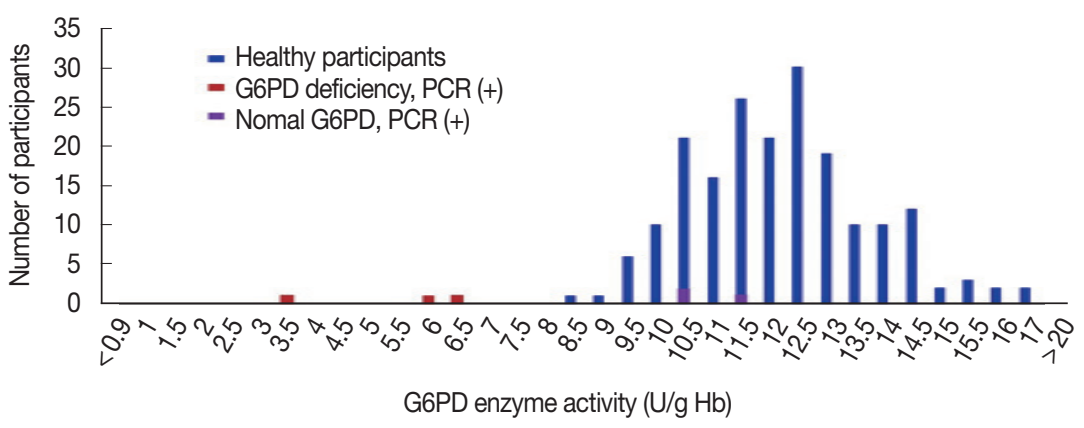

Fig. 1. Distribution of G6PD enzyme activity and genetic variants in the participants in this study. (A) G6PD enzyme activity values for all marriage immigrant women tested in this study; blue bars: participants with normal range G6PD enzyme activity values, red bars: deficient individuals, and green bar: deficient individuals in enzyme activity, but not genotype. (B) G6PD enzyme activity values for all adolescent population tested. (C) G6PD enzyme activity values for male adolescent population tested; blue bars: individuals with normal enzyme activity values, red bars: deficient individuals in enzyme activity and genotype, and green bars: deficient individuals in enzyme activity, but not genotype. (D) G6PD enzyme activity values for female adolescent population tested; blue bars: individuals with normal enzyme activity values, red bars: deficient individuals in enzyme activity and genotype, and purple bars: deficient individuals in genotype, but not enzyme activity. 
Table 5. Correlation of phenotype with genotype by gender in male adolescent population and materfamilias population

\begin{tabular}{|c|c|c|c|c|c|c|}
\hline \multirow{2}{*}{ Participants } & \multirow{2}{*}{ Phenotype } & \multirow{2}{*}{$\begin{array}{c}\text { No. of } \\
\text { participants }\end{array}$} & \multirow{2}{*}{ Genotype } & \multirow{2}{*}{$\begin{array}{c}\text { No. of } \\
\text { participants (\%) }\end{array}$} & \multicolumn{2}{|c|}{ Enzyme activity (U/g Hb) } \\
\hline & & & & & Mean \pm SD & Range \\
\hline \multirow[t]{4}{*}{ Male adolescents ( $n=219)$} & \multirow[t]{2}{*}{ Normal } & \multirow[t]{2}{*}{202} & Wild-type & $202(92.2)$ & \multirow[t]{2}{*}{$12.1 \pm 1.8$} & \multirow[t]{2}{*}{$8.5-22.5$} \\
\hline & & & Hemizygous & $0(0)$ & & \\
\hline & \multirow[t]{2}{*}{ Deficient } & \multirow[t]{2}{*}{17} & Wild-type & $5(2.3)$ & $4.2 \pm 1.2$ & $3.2-6.4$ \\
\hline & & & Hemizygous & $12(5.5)$ & $0.6 \pm 0.4$ & $<0.5-1.7$ \\
\hline \multirow[t]{6}{*}{ Female adolescents ( $n=198)$} & \multirow[t]{3}{*}{ Normal } & \multirow[t]{3}{*}{194} & Wild-type & $192(97.0)$ & $12.4 \pm 1.8$ & 8.9-22.1 \\
\hline & & & Heterozygous & $3(1.5)$ & \multirow[t]{3}{*}{$10.9 \pm 0.5$} & \multirow[t]{3}{*}{$10.5-11.7$} \\
\hline & & & Homozygous & 0 & & \\
\hline & \multirow{3}{*}{ Deficient } & \multirow[t]{3}{*}{4} & Wild-type & 0 & & \\
\hline & & & Heterozygous & $4(2.0)$ & \multirow[t]{2}{*}{$5.5 \pm 1.1$} & \multirow[t]{2}{*}{$3.8-6.5$} \\
\hline & & & Homozygous & 0 & & \\
\hline \multirow[t]{7}{*}{ Materfamilias $(n=316)$} & \multirow[t]{3}{*}{ Normal } & \multirow[t]{3}{*}{306} & Wild-type & $291(92.1)$ & $11.8 \pm 2.5$ & $8.1-20.5$ \\
\hline & & & Heterozygous & $15(4.7)$ & \multirow[t]{2}{*}{$9.7 \pm 1.1$} & \multirow[t]{2}{*}{$8-12.1$} \\
\hline & & & Homozygous & 0 & & \\
\hline & \multirow[t]{4}{*}{ Deficient } & \multirow[t]{4}{*}{10} & Wild-type & $2(0.6)$ & 6.2 & $6.1-6.2$ \\
\hline & & & Heterozygous & $7(2.2)$ & $4.2 \pm 1.8$ & $2.6-6.2$ \\
\hline & & & Compound & $1(0.3)$ & $<0.5$ & $<0.5$ \\
\hline & & & Heterozygous & & & \\
\hline Total & & 733 & & 733 & & \\
\hline
\end{tabular}

more, diversification of genetic sources due to each regional genetic characteristic can cause problems in many aspects. There is substantial room for improvement in radical cure policies and practices. Most of the current guidelines for the radical treatment of vivax malaria recommend the use of primaquine $(0.25 \mathrm{mg} / \mathrm{kg}$ of body weight) for 2 weeks overlapping with the radical treatment with blood schizonticide agents, such as chloroquine $(5 \mathrm{mg} / \mathrm{kg}$, 3 times with $12 \mathrm{hr}$ interval after first dose (10 mg/kg) or $5 \mathrm{mg} / \mathrm{kg}$ once with $24 \mathrm{hr}$ interval after the first and second doses $(10 \mathrm{mg} / \mathrm{kg})$ [20]. However, the downside of guidelines recommended by the Korea Disease Control and Prevention Agency is that primaquine, which is the only available antimalaria drug that kills dormant liver stages of P. vivax and prevents its relapse, can be toxic to individuals with G6PD deficiency. Nowadays, no treatment guidelines in Korea have been issued that account for the G6PD deficiency. Several reports presented that no G6PD deficiency was observed using phenotypic- or genotypic-based tests in individuals and young soldiers residing in vivax malaria endemic regions in Korea [10,11].

The population of multicultural families consisting of a marriage immigrant or foreigner with Korean citizenship, have been rapidly growing in Korea since 2000. While international migration has become a global phenomenon over recent decades, Korea has experienced this phenomenon relatively recently. Among the registered foreign population in 2018, 6.7\%
$(159,206 / 2,367,607)$ were marriage migrants, which were the second largest group, following migrant workers [21]. 83.2\% $(132,391 / 159,206)$ of the international marriages were between a Korean groom and foreign bride. Consequently, the number of adolescents in multicultural families was 122,212 in 2018 in Korea and tends to continuously increase annually [22]. Adolescents in multicultural families accounted for 2.2\% of the total Korean adolescent population in 2018, which is over 3 times higher than that in $2012(0.7 \%)$ [22]. In this study, we found overall $7.8 \%$ of participants with G6PD deficiency in male adolescent participants. In the case of the marriage immigrant women (the materfamilias population), $3.2 \%$ of participants showed G6PD deficiency. The above results suggest that our country should also seriously consider establishing guidelines for prescriptions on primaquine currently in use to treat malaria and to prevent the significant toxic effects accompanying this drug usage.

This study was designed to identify the prevalence of G6PD deficiency in multicultural families in Korea by maternal immigration and strengthen patient care as a strategy for implementing a 5-year action plan to eliminate malaria again. Through this, the government sought to secure evidence for the rapid diagnosis of anemia for the safety of patients. The G6PD deficiency is high in Southeast Asia, the Middle East, the Mediterranean coast, the South Pacific islands and Africa, but the global population migration, inter-country exchanges, 
and marriage are increasing worldwide. This raises concerns over the development of hemolytic anemia caused by primaquine drugs. In this study, a total of 733 blood samples were collected in 7 counties (Goseong, Yangyang, Haenam, Hampyeong, Hwasun, Boseong, and Yeoncheon) and 2 cities (Donghae and Taebaek) of Korea. On blood samples, a G6PD enzyme activity test using G6PD quantitative kinetic UV assay on whole blood kit was performed. Based on classification by the WHO, 12 severe ( $<10 \%$ of the median enzyme activity) phenotypic participants, 9 moderate $(10 \%$ to $<30 \%)$ ones, and 10 mild ( $30 \%$ to $<60 \%$ ) ones were identified and $4.2 \%$ of the participants in this study were with G6PD deficiency. Simultaneously with blood collection, hemoglobin levels were measured to monitor whether specimen were anemic. No subject from the regions where were collected in this study had a medical history of vivax malaria infection. The current surveillance has been conducted on malaria non-endemic areas, and it is thought that future investigations into G6PD deficiency in malaria endemic areas, especially the marriage immigrant women (the materfamilias population) and their next adolescent generation including the registered foreign populations, will be needed continuously and with a wide range of targets.

In conclusion, there are at least 6 G6PD variants (Viangchan, Canton, Vanua Lava, Union, Kaiping, unknown mutation (s)) in the population of multicultural families consisting the materfamilias and their adolescents. Possible reasons for the detected other unknown mutated allele variants are that another mutant that were impossible to be identified by the kit used in this experiment can be expected to exist or to be other type mutant. So far, it is acceptable in Korea that G6PD deficiency prevalence is low enough that the risk of antimalaria drug, primaquine-originated G6PD deficiency-mediated hemolytic anemia is relatively negligible. However, in this study, the population of multicultural families, particularly in adolescent population, have carried G6PD deficiency. In addition, although the G6PD deficient individuals with activity $<30 \%$ of the median value is not identified, large number of military personnel with C1311T/IVS and T93C intron mutations, which are recognized to be associated with G6PD deficiency, were identified [11]. There are also the recent case reports of G6PD deficiency-mediated hemolytic anemia in the malaria endemic area [23-25]. Therefore, when it is considered that the genetic variants in G6PD associated with enzyme activity deficiency exists in Korean population, that primaquine chemo- prophylaxis is carried out routinely in military personnel in the vivax malaria endemic area, and that there are somehow case reports for G6PD deficiency in the endemic area, further regular surveillance of G6PD deficiency and radical treatment guidelines are needed to ensure the safe administration of the unique anti-vivax malaria drug, primaquine.

\section{ACKNOWLEDGMENT}

This study was supported by the Korea Disease Control and Prevention Agency (4851-304-320) and the National Research Foundation of Korea (NRF) grants funded by the Korean Government (NRF-2019K1A3A9A01000005 and NRF-2017M3A9B8069530).

\section{CONFLICT OF INTEREST}

The authors declare that there is no conflict of interest regarding the publication of this article.

\section{REFERENCES}

1. Chen EY, Cheng A, Lee A, Kuang WJ, Hillier L, Green P, Schlessinger D, Ciccodicola A, D'Urso M. Sequence of human glucose6-phosphate dehydrogenase cloned in plasmids and a yeast artificial chromosome. Genomics 1991; 10: 792-800. https://doi. org/10.1016/0888-7543(91)90465-q

2. Cappellini MD, Fiorelli G. Glucose-6-phosphate dehydrogenase deficiency. Lancet 2008; 371: 64-74. https://doi.org/ 10.1016/ S0140-6736(08)60073-2

3. Luzzatto L, Nannelli C, Notaro R. Glucose-6-phhosphate dehydrogenase deficiency. Hematol Oncol Clin North Am 2016; 30: 373-393. https://doi.org/ 10.1016/j.hoc.2015.11.006

4. Vulliamy T, Mason P, Luzzatto L. The molecular basis of glucose6-phosphate dehydrogenase deficiency. Trends Genet 1992; 8: 138-143. https://doi.org/10.1016/0168-9525(92)90372-B

5. WHO Working Group. Glucose-6-phosphate dehydrogenase deficiency. Bull World Health Organ 1989; 67: 601-611. https:// www.ncbi.nlm.nih.gov/pmc/articles/PMC2491315/

6. Motulsky AG. Metabolic polymorphisms and the role of infectious diseases in human evolution. Hum Biol 1960; 32: 28-62. https://www.proquest.com/docview/1301845591?pq-origsite=gs cholar\&fromopenview=true\&imgSeq $=1$

7. Marla KJ, Tamara DC, Njama-Meya D, Rosenthal PJ, Sunil P. Impact of the method of G6PD deficiency assessment on genetic association studies of malaria susceptibility. PLoS One. 2009; 4: e7246. https://doi.org/10.1371/journal.pone.0007246

8. Verlé P, Nhan DH, Tinh TT, Uyen TT, Thuong ND, Kongs A, Stuyft P, Coosemans M. Glucose-6-phosphate dehydrogenase deficiency in northern Vietnam. Trop Med Int Health 2000; 5: 
203-206. https://doi.org/10.1046/j.1365-3156.2000.00542.x

9. Saha N. Distribution of glucose-6-phosphate dehydrogenase phenotypes in five East Asian population groups. Ann Acad Med Singap 1984; 13: 494-497. https://pubmed.ncbi.nlm.nih.gov/ 6517516/

10. Goo YK, Ji SY, Shin HI, Moon JH, Cho SH, Lee WJ, Kim JY. First evaluation of glucose-6-phosphate dehydrogenase (G6PD) deficiency in vivax malaria endemic regions in the Republic of Korea. PLoS One 2014; 9: e97390. https://doi.org/10.1371/journal. pone.0097390

11. Lee W, Lee SE, Lee MJ, Noh KT. Investigation of glucose-6-phosphate dehydrogenase (G6PD) deficiency prevalence in a Plasmodium vivax-endemic area in the Republic of Korea. Malar J 2020; 19: 317. https://doi.org/10.1186/s12936-020-03393-4

12. Beutler E. G6PD: Population genetics and clinical manifestations. Blood Rev 1996; 10: 45-52. https://doi.org/10.1016/s0268960x(96)90019-3

13. Bahk YY, Lee HW, Na BK, Kim J, Jin K, Hong YS, Kim TS. Epidemiological characteristics of re-emerging vivax malaria in the Republic of Korea. Korean J Parasitol 2018; 56: 531-543. https:// doi.org/10.3347/kjp.2018.56.6.531

14. Ashley EA, Recht J, White NJ. Primaquine: the risks and the benefits. Malar J 2014; 12: 1. https://doi.org/10.1186/1475-2875-13418

15. World Health Organization. Guideline for the Treatment of Malaria. 3rd ed. Geneva, Switzerland. WHO Press. 2015. https:// www.afro.who.int/publications/guidelines-treatment-malariathird-edition

16. Recht J, Ashley EA, White NJ. Use of primaquine and glucose6-phosphate dehydrogenase deficiency testing: divergent policies and practices in malaria endemic countries. PLoS Negl Trop Dis 2018; 12: e0006230. https://doi.org/10.1371/journal.pntd. 0006230

17. Lee J, Park J, Choi H, Kim J, Kwon A, Jang W, Chae H, Kim M,
Kim Y, Lee JW, Chung NG, Cho B. Genetic profiles of Korean patients with glucose-6-phosphate dehydrogenase deficiency. Ann Lab Med 2017; 37: 108-116. https://doi.org/10.3343/alm. 2017.37.2.108

18. Korean Statistical Information Service (KOSIS). Korean social trends 2019 (11-1240245-00014-10) [Internet]. Available from: http://sri.kostat.go.kr

19. Jalil N, Azma RZ, Mohamed E, Ithnin A, Alauddin H, Baya SN, Othman A. Evaluation of glucose-6-phosphatase dehydrogenase stability in stored blood samples. EXCLI J 2016; 15: 155-162. https://doi.org/10.17179/excli2015-604

20. World Health Organization. WHO Guidelines for Malaria. Geneva, Switzerland. WHO Press. 2021. https://www.who.int/publications/i/item/guidelines-for-malaria

21. Statistics Korea. Status of Foreign Residents [Internet]. Available from: https://www.index.go.kr/potal/main/EachDtlPageDetail. do?idx_cd=2756

22. Statistics Korea. The Adolescents People: 2019 [Internet]. Available from: https://www.kostat.go.kr/portal/korea/kor_nw/1/1/ index.board?bmode=read\&aSeq $=374490$

23. Kim MK, Yang CH, Kang SH, Lyu CJ, Kim KY. Glucose-6-phosphate dehydrogenase deficiency-report of 4 cases. J Korean Med Sci 1992; 7: 71-5. https://doi.org/10.3346/jkms.1992.7.1.71

24. Lee J, Park J, Choi H, Kim J, Kwon A, Jang W, Chae H, Kim M, Kim Y, Lee JW, Chung NG, Cho B. Genetic profiles of Korean patients with glucose-6-phosphate dehydrogenase deficiency. Ann Lab Med 2017; 37: 108-116. https://doi.org/10.3343/alm. 2017.37.2.108

25. Jang MA, Kim JY, Lee KO, Kim SH, Koo HH, Kim HJ. A novel de novo mutation in the G6PD gene in a Korean boy with glucose6-phosphate dehydrogenase deficiency: case report. Ann Clin Lab Sci 2015; 45: 446-448. http://www.annclinlabsci.org/content/45/4/446.long 
